\title{
Biotic, Molecular, and Phylogenetic Characterization of Bean Calico Mosaic Virus, a Distinct Begomovirus Species with Affiliation in the Squash Leaf Curl Virus Cluster
}

\author{
J. K. Brown, Kristin M. Ostrow, Ali M. Idris, and Drake C. Stenger
}

First and third authors: Department of Plant Sciences, University of Arizona, Tucson 85721; and second and fourth authors: Department of Biological Sciences, Northern Illinois University, DeKalb 60115.

Current address of K. M. Ostrow: McArdle Laboratory for Cancer Research, Medical School, University of Wisconsin, Madison 53706.

Current address of D. C. Stenger: USDA-ARS and Department of Plant Pathology, University of Nebraska, Lincoln 68583.

Accepted for publication 7 January 1999.

\begin{abstract}
Brown, J. K., Ostrow, K. M., Idris, A. M., and Stenger, D. C. 1999. Biotic, molecular, and phylogenetic characterization of bean calico mosaic virus, a distinct Begomovirus species with affiliation in the squash leaf curl virus cluster. Phytopathology 89:273-280.

Bean calico mosaic virus (BCMoV), a whitefly-transmitted geminivirus from Sonora, Mexico, was purified, and the genome components were cloned and sequenced. Purified viral fractions and cloned genome components were infectious by biolistic inoculation to bean, completing Koch's postulates for both. The B biotype of the whitefly Bemisia tabaci efficiently transmitted both native virus and progeny virus derived from cloned DNA inoculum. Host ranges of native virus and of progeny virus derived from cloned DNA were identical based upon whitefly and biolistic mediated transmission, respectively. $\mathrm{BCMoV}$ has a relatively wide experimental host range among begomoviruses known to infect bean, encompassing genera and species within the Fabaceae, Malvaceae, and Solanaceae. BCMoV has a bipartite genome, as do other New World

shared highest nucleotide sequence identity with SLCV-E at 70.7\%. The common region (CR) sequences of BCMoV and SLCV-E are 73 to $76 \%$ identical; however, modular cis-acting elements within the CR involved in replication origin function and recognition are $100 \%$ conserved. Phylogenetic analysis indicated that BCMoV DNA-A shares a most recent common ancestor with the DNA-A of two viruses that also occur in the Sonoran Desert, SLCV-E and Texas pepper virus (TPV-TAM), and CaLCV from Florida. In contrast, a phylogenetic analysis indicated that BCMoV DNA-B shares a most recent common ancestor with SLCV-E; whereas DNA-B of CaLCV clustered in a separate clade with pepper hausteco virus. Collectively, biological and molecular characteristics indicate that $\mathrm{BCMoV}$ is a distinct begomovirus species with the northernmost distribution of any begomovirus isolated from bean in the Americas. Furthermore, the phylogenetic relationships of begomovirus cognate components are not necessarily identical, suggesting that DNAA and DNA-B of some begomoviruses may have different evolutionary histories.
\end{abstract} begomoviruses. BCMoV DNA-A shared highest nucleotide sequence identities with squash leaf curl virus-E strain (SLCV-E) and cabbage leaf curl virus $(\mathrm{CaLCV})$ at 80.1 and $80.7 \%$, respectively. BCMoV DNA-B
Additional keywords: legume virus, Phaseolus virus, PAUP, virus taxonomy, whitefly-transmitted virus.
Whitefly-transmitted geminiviruses have emerged as serious pathogens of agronomic and horticultural crops in subtropical and tropical regions of the Americas $(4,5,47)$. Whitefly-transmitted geminiviruses are restricted to dicotyledonous plants and are assigned to the genus Begomovirus (formerly Subgroup III) within the family Geminiviridae (39). Begomoviruses originating in the New World have a bipartite genome organization; whereas begomoviruses from the Old World have either bipartite or monopartite genomes.

DNA-A and DNA-B of bipartite begomoviruses are each approximately $2.6 \mathrm{~kb}$ and share a common region (CR) of approximately 200 nucleotides that is highly conserved among cognate components of a single virus species. The CR contains modular cis-acting elements of the origin of replication (ori) $(19,37,41)$. Five open reading frames (ORFs) capable of encoding proteins $>10 \mathrm{kDa}$ are conserved among the DNA-A of begomoviruses. The capsid protein (CP) is encoded by the ORF (AV1) most highly conserved among begomoviruses (43). The Rep protein encoded by the AC1 ORF initiates viral DNA replication $(26,35)$, and specificity of replication is mediated through interactions of Rep with

Corresponding author: J. K. Brown; E-mail address: jbrown@ag.arizona.edu

Publication no. P-1999-0216-01R

This article is in the public domain and not copyrightable. It may be freely reprinted with customary crediting of the source. The American Phytopathological Society, 1999. cis-acting elements of the ori $(12,18,20,23,33,41,42)$. The begomovirus DNA-B encodes two polypeptides, BV1 and BC1, both of which are essential for systemic movement $(16,24,31,32,45,51)$ and can influence host range $(31,52)$.

Geminivirus diseases in tropical and subtropical regions of the Americas are major impediments to bean production. Caribbean Basin isolates of bean golden mosaic virus (BGMV) from Puerto Rico (BGMV-PR) (29), the Dominican Republic (BGMV-DR) (17), and Guatemala (BGMV-GA) (17) have been completely sequenced and constitute a single begomovirus species $(17,43)$. Two additional begomoviruses of bean in the Americas also have been completely sequenced: bean dwarf mosaic virus (BDMV) from Colombia (27) and bean golden mosaic virus from Brazil (BGMV-BR, formerly BGMV-BZ) (21). BDMV and BGMV-BR are separate species and are distinct from all BGMV isolates known from the Caribbean Basin. A comprehensive phylogenetic treatment of the family Geminiviridae (43) affiliates BDMV with the begomovirus cluster containing Abutilon mosaic virus (AbMV) and other related members. BGMVBR DNA-B shares a most recent common ancestor with another Brazilian begomovirus, tomato golden mosaic virus (TGMV); whereas DNA-A of BGMV-BR most closely resembles those of species within the AbMV cluster (43).

A fourth whitefly-transmitted geminivirus of bean was discovered in Sonora, Mexico, in 1986 (7,9) and was provisionally designated bean calico mosaic virus (BCMoV). BCMoV was considered different from other bean-infecting geminiviruses known at 

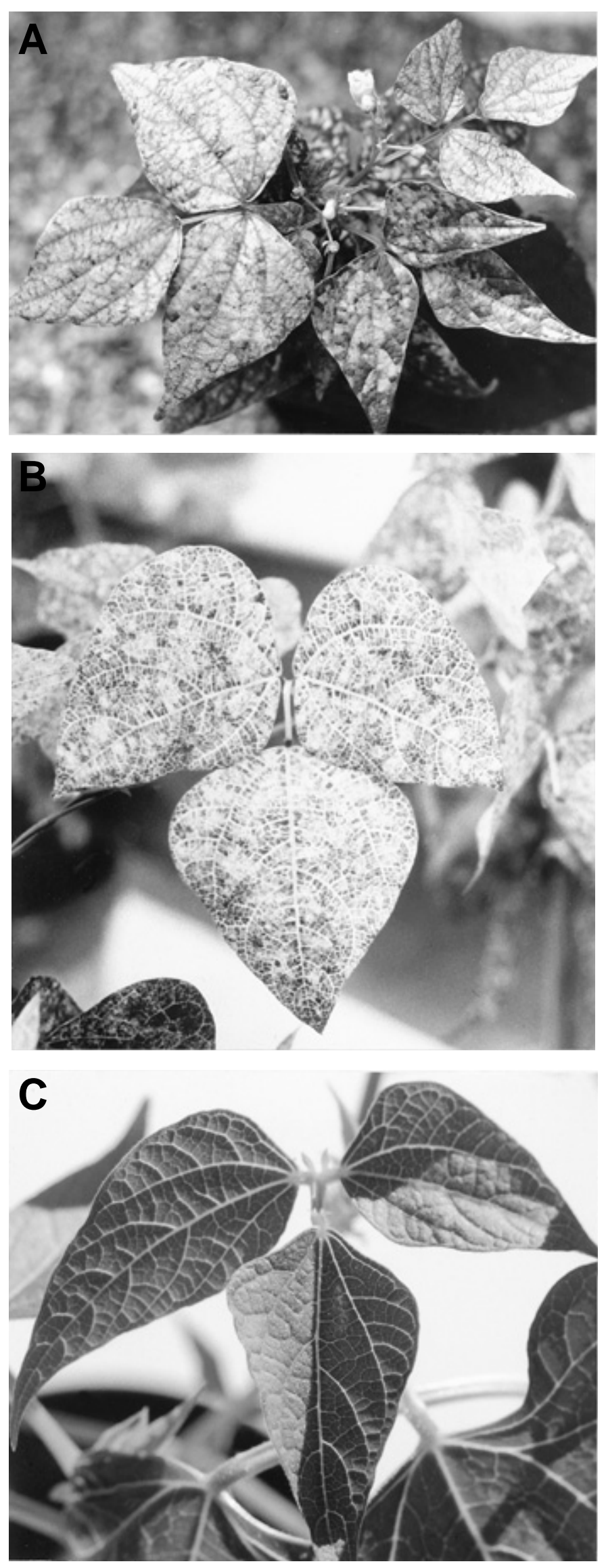

Fig. 1. A, Common bean (Phaseolus vulgaris) cv. Red Kidney with typical symptoms of bean calico mosaic virus (BCMoV) infection, B, typical symptoms in Red Kidney bean infected with bean golden mosaic virus-Puerto Rico, and $\mathbf{C}$, uninfected, asymptomatic bean. the time based upon a distinct host range, bright yellow/white calico and mosaic symptoms produced in infected beans (Fig. 1A-C), and differential hybridization with a diverse panel of geminivirus DNA probes $(7,54)$. Analysis of partial genomic sequences of the AC1 ORF and CR corroborated these results $(17,38)$. Here, we describe in detail the biotic and molecular characteristics of native $\mathrm{BCMoV}$ and of infectious DNA clones derived from the native virus culture. We also describe the phylogenetic relationship of $\mathrm{BCMoV}$ to other begomoviruses and present a hypothesis to explain differential evolution of begomovirus DNA-A and DNA-B components.

\section{MATERIALS AND METHODS}

Virus isolate. BCMoV was collected from symptomatic bean near Hermosillo, Sonora, Mexico, in 1986 (9). This native viral culture was maintained in the greenhouse in bean (Phaseolus vulgaris L.) plants either by serial transmission using the whitefly vector, Bemisia tabaci (Gennadius), or by biolistic inoculation (50) of bean with DNA extracted from infected plants.

Experimental host range of native BCMoV. Plants used for experimental host range studies included cultivated crop or weed species common to the Sonoran Desert agroecosystem. Test plants examined here were several species of bean (Phaseolus spp.), cotton (Gossypium hirsutum) cv. DP90, Datura stramonium L., eggplant (Solanum melongena L.) cv. Black Beauty, Malva parviflora L., okra (Hibiscus esculentus L.) cv. Clemson Spineless, pepper (Capsicum annuum L.) cv. Anaheim, pumpkin (Cucurbita maxima Duchesne) cv. Big Max, soybean (Glycine max (L.) Merr.), tobacco (Nicotiana tabacum L.) cv. Samsun, N. benthamiana Domin., and tomato (Solanum lycopersicon L. (Karsten)) cv. Pole Boy. At least four seedlings of each species were inoculated with $\mathrm{BCMoV}$ using 15 to 20 viruliferous adult whiteflies. Bean plants infected with native $\mathrm{BCMoV}$ were source plants for virus acquisition by whiteflies. Parameters used for whitefly transmission were a 24-h acquisition access period (AAP) followed by a 48-h inoculation access period (IAP). Whitefly transmission experiments were carried out in an environmentally controlled growth chamber $\left(27^{\circ} \mathrm{C}, 12 / 12 \mathrm{~h}\right.$ day/night cycle). Experimental controls consisted of plants exposed to a virus-free whitefly colony and whitefly-free plants. Transmission experiments were terminated by killing whiteflies with nicotine sulfate, and thereafter inoculated plants were maintained in an insect-free greenhouse $\left(23\right.$ to $\left.28^{\circ} \mathrm{C}\right)$ with ambient light. Test plants inoculated with native virus were bioassayed for BCMoV infection 2 to 3 weeks postinoculation by whitefly transmission (15 to 20 whiteflies per plant) to bean cv. Red Kidney seedlings (3- to 4-leaf stage) using a 24-h AAP on inoculated test plants followed by a 48-h IAP on bean indicator plants. Inoculated indicator plants were held as described above.

Purification, transmission electron microscopy (TEM), and infectivity assays of native BCMoV. Leaves from bean plants whitefly-inoculated with native $\mathrm{BCMoV}$ or from uninoculated bean plants were harvested 10 days postinoculation. Leaves (100 to $120 \mathrm{~g}$ ) were ground in liquid nitrogen and homogenized with a blender in $0.1 \mathrm{M}$ potassium phosphate buffer, $\mathrm{pH}$ 8.0. The homogenate was brought to a final concentration of $2 \%$ Triton $\mathrm{X}$ 100 , stirred for $16 \mathrm{~h}$ at $4^{\circ} \mathrm{C}$, and centrifuged in a Beckman JA20 rotor at 10,000 maximum relative centrifugal force $\left(\mathrm{RCF}_{(\max )}\right)$ for $10 \mathrm{~min}$ at $4^{\circ} \mathrm{C}$. The supernatant was placed over a $20 \%$ sucrose cushion (in $0.05 \mathrm{M}$ potassium phosphate buffer, $\mathrm{pH}$ 8.0) and centrifuged in an SW28 rotor $\left(131,000 \mathrm{RCF}_{(\max )}, 3 \mathrm{~h}, 4^{\circ} \mathrm{C}\right)$. Pellets were resuspended in cold TE $(10 \mathrm{mM}$ TRIS-HCl, $1 \mathrm{mM}$ EDTA, $\mathrm{pH}$ 8.0) buffer and centrifuged in a Beckman JA20 rotor $(6,000$ $\left.\mathrm{RCF}_{(\max )}, 10 \mathrm{~min}, 4^{\circ} \mathrm{C}\right)$. Supernatants $(\sim 1 \mathrm{ml})$ were loaded onto 10 to $30 \%$ sucrose gradients in TE buffer and centrifuged in a Beckman SW50.1 rotor $\left(276,000 \mathrm{RCF}_{(\max )}, 2 \mathrm{~h}, 4^{\circ} \mathrm{C}\right)$. Sucrose gradients of samples from infected plants yielded a light-scattering zone from which virions were precipitated by addition of polyethylene glycol at a final concentration of $4 \%$ and sodium chloride at a 
final concentration of $0.2 \mathrm{M}$. The precipitate was recovered by centrifugation in a Beckman JA20 rotor $\left(12,000 \mathrm{RCF}_{(\max )}, 10 \mathrm{~min}\right.$, $4^{\circ} \mathrm{C}$ ), and the pellets containing virions were resuspended in TE.

For TEM, droplets $(10 \mu \mathrm{l})$ of the light-scattering virus fraction from sucrose gradients were pipetted onto Formvar-coated copper grids and incubated for $5 \mathrm{~min}$, after which the droplets were removed and each replaced with a second $10-\mu 1$ droplet. Grids were washed with double-distilled water, blotted, floated on $2 \%$ uranyl acetate (UA), and air-dried. Prepared grids were examined using an Hitachi-500 transmission electron microscope at $60 \mathrm{kV}$.

Encapsidated DNA was recovered from purified virion fractions for use in infectivity assays. Virion suspensions were incubated with $5 \mu \mathrm{l}$ of DNase $(1 \mathrm{mg} / \mathrm{ml})$ for $4 \mathrm{~h}$ at $4{ }^{\circ} \mathrm{C}$ to remove residual unencapsidated DNA. Encapsidated DNA was released from virions by incubating the suspension for $1 \mathrm{~h}$ at $55^{\circ} \mathrm{C}$ after the addition of sodium dodecyl sulfate to a final concentration of $1 \%$ and proteinase $\mathrm{K}$ to a final concentration of $20 \mu \mathrm{g} / \mathrm{ml}$. DNA released from virions was extracted twice with phenol:chloroform:isoamyl alcohol (50:49:1), ethanol precipitated, and resuspended in $35 \mu \mathrm{l}$ of cold TE. Purified virion DNA $(1 \mu \mathrm{g})$ was precipitated onto microprojectiles and assayed by biolistic inoculation to bean seedlings (50). Plants were scored positive for infectivity based on development of BCMoV symptoms 8 to 12 days postinoculation. Infectivity experiments were replicated twice, each time with a different viral DNA preparation.

Molecular cloning and sequencing of the $\mathrm{BCMoV}$ genome. Total DNA extracted from bean infected with BCMoV contained low but detectable amounts of viral single-stranded and doublestranded (ds) DNA when stained with ethidium bromide after electrophoresis in an agarose gel (data not shown). Aliquots of the total DNA sample extracted from $\mathrm{BCMoV}$-infected bean were incubated with various restriction enzymes, and the products were analyzed by Southern hybridization using riboprobes of virionsense transcribed from pSLCV10-S46 (DNA-A) and pSLCV10E1 (DNA-B). pSLCV10-S46 and pSLCV10-E1 (D. C. Stenger and K. M. Ostrow, unpublished) contain full-length inserts of the genome components derived from a wide host range isolate of squash leaf curl virus (SLCV) previously designated by the synonym melon leaf curl virus (15). As digestion with Csp45 I appeared to completely linearize dsDNA forms of BCMoV observed in Southern hybridizations (data not shown), Csp45 I was used to clone both BCMoV components. Csp45 I-linearized BCMoV dsDNA was size selected and recovered from an agarose gel and ligated to Csp45 I-digested pGEM7zf+ (Promega, Madison, WI). Clones bearing recombinant plasmids containing approximately 2.6-kbp inserts of BCMoV DNA-A or -B were identified by colony hybridization using riboprobes transcribed from pSLCV10S46 or pSLCV10-E1. Two recombinant plasmids containing fulllength Csp45 I inserts of BCMoV DNA-A (pBCMoV-C58) or DNA-B (pBCMoV-C4) were selected for subsequent analyses.

A series of nested deletions was constructed in both directions for $\mathrm{pBCMoV-C58}$ and $\mathrm{pBCMoV}-\mathrm{C} 4$ using the Erase-a-Base kit supplied by Promega. Plasmids cloned from the Erase-a-Base procedure served as templates that were sequenced with an ABI 373 automated sequencer. Sequences were compiled and searched for potential ORFs using the DNA Inspector IIe program (Textco, New Lebanon, NH). The complete nucleotide sequences of BCMoV DNA-A and -B have been deposited as GenBank accession numbers AF110189 and AF110190. The distribution of sequence identity among BCMoV and selected begomoviruses was determined using the dot matrix plot option of DNA Inspector IIe, using a window size of $20 \mathrm{nu}-$ cleotides and a maximum mismatch tolerance of 3 nucleotides per window.

Infectivity and host range of cloned BCMoV. Plasmids bearing tandemly repeated copies of the cloned inserts of BCMoV DNA-A (pBCMoV-C58D) or DNA-B (pBCMoV-C4D) were constructed in pGEM7zf+ essentially as described (53) and delivered to test plants by biolistic inoculation as a mixture containing $0.5 \mu \mathrm{g}$ of each plas- mid. Inoculated plants were maintained in a whitefly-free greenhouse and monitored for symptom development. The same plant species used in the host range study of native $\mathrm{BCMoV}$ were biolistically inoculated with cloned $\mathrm{BCMoV}$ DNAs to facilitate a direct comparison of experimental host range and symptom expression. Seedlings (four each) of test plants inoculated with cloned $\mathrm{BCMoV}$ DNAs were confirmed as positive or negative for infection by polymerase chain reaction (PCR) using universal, degenerate primers that amplify a begomovirus-diagnostic fragment of $576 \mathrm{bp}$ (57). Total DNA was extracted (14) from clone-inoculated test plants 2 to 3 weeks postinoculation and analyzed by PCR (data not shown). PCR primers, reaction conditions, and visualization of PCR products were as described (57). DNA extracts $(10 \mu \mathrm{l})$ that were positive for begomovirus infection served as inocula for back-indexing to indicator bean plants by biolistic inoculation. The development of typical BCMoV symptoms in back-indexed beans was considered confirmation of $\mathrm{BCMoV}$ infection in the original test plants.

Serial passage of cloned $\mathrm{BCMoV}$ by the whitefly vector. The ability of whiteflies to transmit progeny virus derived from cloned inoculum was assessed by allowing 15 to 20 whiteflies a 24-h AAP on source bean plants and a 48-h IAP on healthy bean seedlings. Three replicated experiments were conducted with three to five plants each for three passages of progeny virus originating from cloned DNA inoculum. Inoculated plants were fumigated to kill whiteflies, and plants were maintained for 12 days in a growth chamber under the conditions described above. The appearance of characteristic BCMoV symptoms in bean 8 to 12 days postinoculation was considered proof of virus infection, and that progeny virus was whitefly transmissible.

Phylogenetic analysis of geminivirus sequences. Geminiviruses used in comparative sequence analyses with their respective GenBank accession numbers shown parenthetically were for DNAA component/monopartite genome viruses: AbMV-WI $\{$ X15983\}, African cassava mosaic virus-Kenya (ACMV-Ke) $\{$ J02057\}, Ageratum yellow vein virus (AYVV) $\{$ X74516\}, BDMV \{M88179\}, BGMV-BR \{M88686\}, BGMV-DR \{L01635\}, BGMV-GA \{M91604\}, BGMV-PR \{M10070\}, beet curly top virus-California (BCTV-CAL) \{M24597\}, cabbage leaf curl virus (CaLCV) \{U65529\}, chayote mosaic virus (ChMV) \{AJ223191\}, cotton leaf curl virus-Pakistan (CLCuV-Pak448) \{AJ0002448\}, East African cassava mosaic virus-Tanzania (EACMV-TAN) $\{$ Z83256 $\}$, Indian cassava mosaic virus (ICMV) \{Z24758\}, Indian tomato leaf curl virus (IToLCV) $\{$ Z48182\}, maize streak virus-Kenya (MSV-KE) $\{$ X01089\}, mung bean yellow mosaic virus (MYMV) \{D14703\}, pepper huasteco virus (PHV) $\{\mathrm{X} 70418\}$, Texas pepper virus-Tamaulipas (TPVTAM) $\{$ U57457\}, potato yellow mosaic virus (PYMV) $\{$ D00940\}, Sida golden mosaic virus (SiGMV) $\{$ X99550 $\}$, South African cassava mosaic virus (SACMV) \{AF011785\}, SLCV-E $\{$ M38183\}, TGMV \{K02029\}, tomato leaf curl virus-Australia (ToLCV-AU) $\{$ S53251\}, tomato leaf curl virus-New Delhi (ToLCV-ND) $\{$ U15015\}, ToLCV-Taiwan (ToLCV-TW) \{U88692\}, tomato mottle virus (ToMoV) $\{\mathrm{L} 14460\}$, tomato yellow leaf curl virus-Israel (TYLCV-IS) $\{$ X15656 $\}$, TYLCV-Sardinia (TYLCV-SAR) $\{$ X61153\}, TYLCVSpain (TYLCV-SP) \{Z25751\}, TYLCV-Thailand (TYLCV-TH) \{M59838\}, and tobacco yellow dwarf virus (TYDV) $\{$ M81103\}. The DNA-B components were ACMV-KE $\{$ J02058\}, AbMV \{X15984\}, BDMV \{M88180\}, BGMV-BR \{M88687\}, BGMV-DR \{L01636\}, BGMV-GA \{M91605\}, BGMV-PR \{U65530\}, CaLCV \{U65530\}, Chino del tomate virus (CdTV) \{U57458\}, ICMV \{Z24759\}, MYMV \{D14704\}, PHV \{X70419\}, PYMV \{D00941\}, SiGMV \{X99551\}, SLCV-E \{M38182\}, TGMV \{K02030\}, ToLCV-ND \{U15017\}, ToMoV \{L14461\}, and TYLCV-TH \{M59839\}.

Phylogenetic analyses comparing BCMoV DNA-A and DNA-B sequences to other geminiviruses available from GenBank were based on distance and maximum parsimony methods. Distance analysis was performed using the Clustal multiple sequence alignment program MegAlign (DNASTAR, Madison, WI). The percent identity between sequences was calculated using the equa- 
tion: $100 \times$ sum of matching residues $\div\{$ length - gap residues (sequence 1) - gap residues (sequence 2) . Trees reconstructed using the Clustal program were further analyzed for maximum parsimony using Phylogenetic Analysis Using Parsimony (PAUP), version 3.1.1 (54). A most parsimonious tree was sought using a heuristic search method, stepwise addition, and the tree-bisectionreconnection random branch-swapping options, for one hundred iterations of bootstrap sampling (10 replicates per iteration). Bootstrap values were calculated using the $>50 \%$ majority rule, and confidence limits were placed at major nodes on the most parsimonious taxonomic reconstructions.

\section{RESULTS}

Purification, TEM, and infectivity of native virus. Three purified preparations of $\mathrm{BCMoV}$ virions recovered from the lightscattering zone of sucrose gradients yielded typical nucleoprotein UV profiles with $260 / 280 \mathrm{~nm}$ optical density ratios ranging between 1.47 and 1.61. Yields of 1.5, 2.4, and $2.6 \mathrm{mg}$ per virion preparation were estimated by UV absorbance at $260 \mathrm{~nm}$, assuming an extinction coefficient of 7.7. Virions of characteristic gemi-
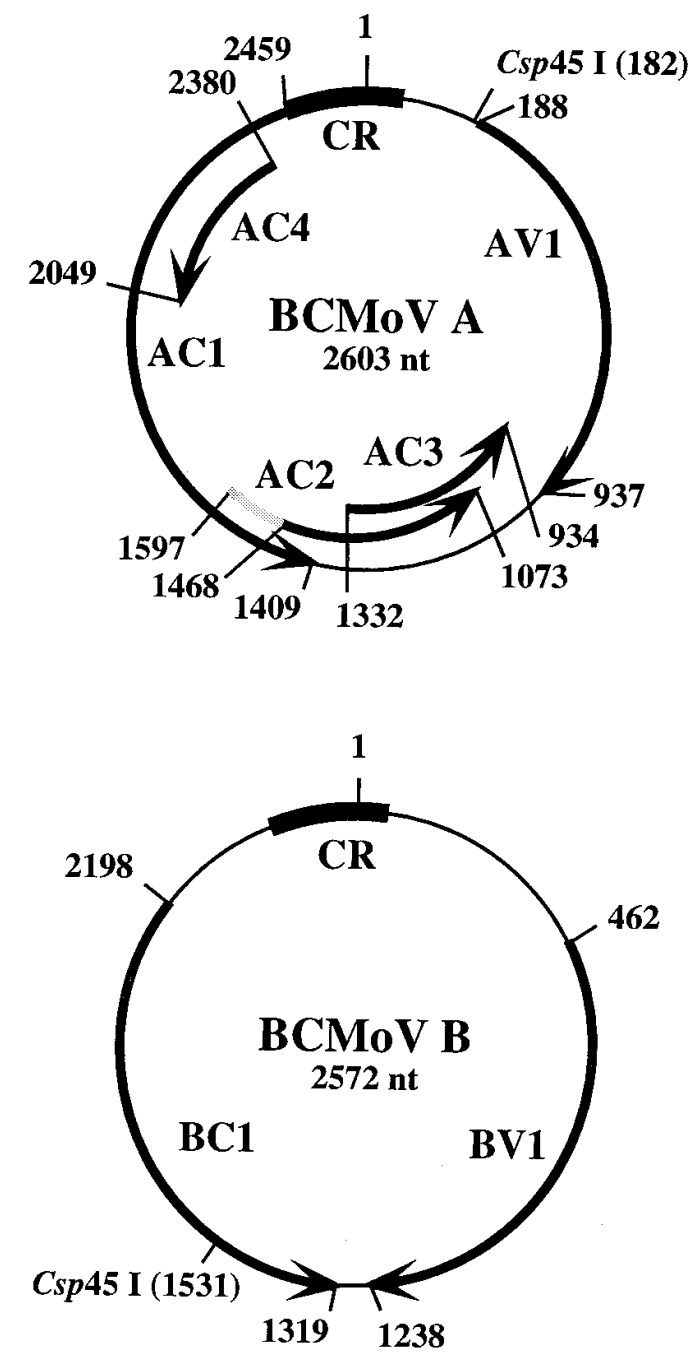

Fig. 2. Physical maps of bean calico mosaic virus (BCMoV) DNA-A and -B. Arrows denote polarity and location of open reading frames (ORFs), arc denotes the location of common region (CR) sequences. Numbers indicate start and stop coordinates for each ORF. Nucleotide 1 is defined as the A residue immediately $3^{\prime}$ of the Rep nick site within the CR. Gray region of the $\mathrm{AC} 2 \mathrm{ORF}$ indicates the portion of the ORF upstream and in-frame of methionine codon that is the conserved start site for AC2 in most begomoviruses. The location and nucleotide coordinates for Csp45 I sites used for cloning each DNA component are indicated. nate shape and size $(20 \times 30 \mathrm{~nm})$ were observed by TEM in negatively stained purified virion preparations. Some monomeric particles were also observed in purified virion preparations. Infectivity was associated only with the light-scattering sucrose gradient fractions containing virions extracted from infected plants. Purified virion DNA inocula biolistically delivered to bean plants resulted in a total of 22/32 plants (results pooled from two experiments) displaying typical $\mathrm{BCMoV}$ symptoms within 12 days postinoculation. Analogous sucrose gradient fractions from uninfected plants were not infectious (0/32 plants).

Host range of native and cloned viruses. Among the plant genera and species inoculated with native $\mathrm{BCMoV}, M$. parviflora, several species of Phaseolus (P. acutifolius PI 510636, lima bean, mung bean, tepary bean, bean cvs. Black Turtle Soup, Red Mexican 34, and Red Kidney), $N$. benthamiana, and tobacco cv. Samsun were virus hosts. Nonhost test species were D. stramonium, eggplant, soybean, tomato, pepper, okra, cotton, and pumpkin. Collectively, the experimental hosts of $\mathrm{BCMoV}$ reside in three plant families: the Fabaceae, Malvaceae, and Solanaceae. Key host species selected to assess the infectivity and symptomatology of cloned BCMoV DNA developed symptoms that were both qualitatively and temporally indistinguishable from those associated with native BCMoV. Specifically, hosts exhibiting characteristic BCMoV symptoms when inoculated with cloned viral DNAs were bean cv. Red Kidney (12/12 plants infected) and tobacco cv. Samsun (10/12 infected); whereas nonhosts were cotton, D. stramonium, eggplant, okra, pepper, pumpkin, soybean, and tomato. Biolistic inoculation to bean indicator plants produced infection only with DNA samples from symptomatic hosts. The diagnostic begomovirus PCR product (576 bp)

TABLE 1. Percent nucleotide identities of the bean calico mosaic virus (BCMoV) DNA-A and -B with those of other geminiviruses

\begin{tabular}{|c|c|c|}
\hline \multirow[b]{2}{*}{ Virus } & \multicolumn{2}{|c|}{ Percent identity $^{\mathrm{a}}$} \\
\hline & DNA-A & DNA-B \\
\hline Abutilon mosaic virus & 70.3 & 63.3 \\
\hline African cassava mosaic virus-Kenya & 59.4 & 44.2 \\
\hline Ageratum yellow vein virus & 62.2 & $\ldots{ }^{b}$ \\
\hline Beet curly top virus-California & 53.9 & $\ldots$ \\
\hline Bean dwarf mosaic virus & 71.2 & 64.2 \\
\hline Bean golden mosaic virus (BGMV)-Brazil & 73.1 & 65.1 \\
\hline BGMV-Dominican Republic & 72.3 & 66.0 \\
\hline BGMV-Guatemala & 72.2 & 65.5 \\
\hline BGMV-Puerto Rico & 72.2 & 65.3 \\
\hline Cabbage leaf curl virus & 80.7 & 63.4 \\
\hline Chino del tomate virus & $\mathrm{NA}^{\mathrm{c}}$ & 63.8 \\
\hline Chayote mosaic virus & 60.9 & NA \\
\hline Cotton leaf curl virus 488 Pakistan & 63.1 & $\ldots$ \\
\hline East African cassava mosaic virus-Tanzania & 60.6 & NA \\
\hline Indian cassava mosaic virus & 62.5 & 34.1 \\
\hline Indian tomato leaf curl virus & 61.4 & $\ldots$ \\
\hline Maize streak virus & 42.1 & $\ldots$ \\
\hline Mung bean yellow mosaic virus & 59.7 & 44.5 \\
\hline Pepper huasteco virus & 65.6 & 63.7 \\
\hline Potato yellow mosaic virus & 71.0 & 61.7 \\
\hline Sida golden mosaic virus & 70.2 & 63.2 \\
\hline South Africa cassava mosaic virus & 60.6 & NA \\
\hline Squash leaf curl virus-E & 80.1 & 70.7 \\
\hline Tomato golden mosaic virus & 72.6 & 67.0 \\
\hline Tomato leaf curl virus (ToLCV)-Australia & 60.7 & $\ldots$ \\
\hline ToLCV-New Delhi & 59.8 & 39.2 \\
\hline ToLCV-Taiwan & 61.0 & $\ldots$ \\
\hline Tomato mottle virus & 71.2 & 64.2 \\
\hline Texas pepper virus-Tamaulipas & 76.7 & NA \\
\hline Tobacco yellow dwarf virus & 40.7 & $\ldots$ \\
\hline Tomato yellow leaf curl virus (TYLCV)-Israel & 61.5 & $\ldots$ \\
\hline TYLCV-Sardinia & 61.1 & $\ldots$ \\
\hline TYLCV-Spain & 61.3 & $\ldots$ \\
\hline TYLCV-Thailand & 61.0 & 34.6 \\
\hline
\end{tabular}

a Distances were calculated by Phylogenetic Analysis Using Parsimony (PAUP) for all pairwise comparisons.

b Monopartite genomes lacking DNA-B.

${ }^{c} \mathrm{NA}=$ not available. 
was readily detectable in samples from symptomatic hosts and undetectable in samples from asymptomatic nonhosts (data not shown).

Whitefly transmission and serial passage of cloned virus. The B biotype vector transmitted progeny of cloned virus from source plants to test plants for three serial passages. Transmission frequencies (data for three replicates pooled) ranged between 75 and 100\%, with 12/15 (passage 1), 12/12 (passage 2), and 9/12 (passage 3) test plants exhibiting BCMoV symptoms within 12 days postinoculation.

\section{Component}

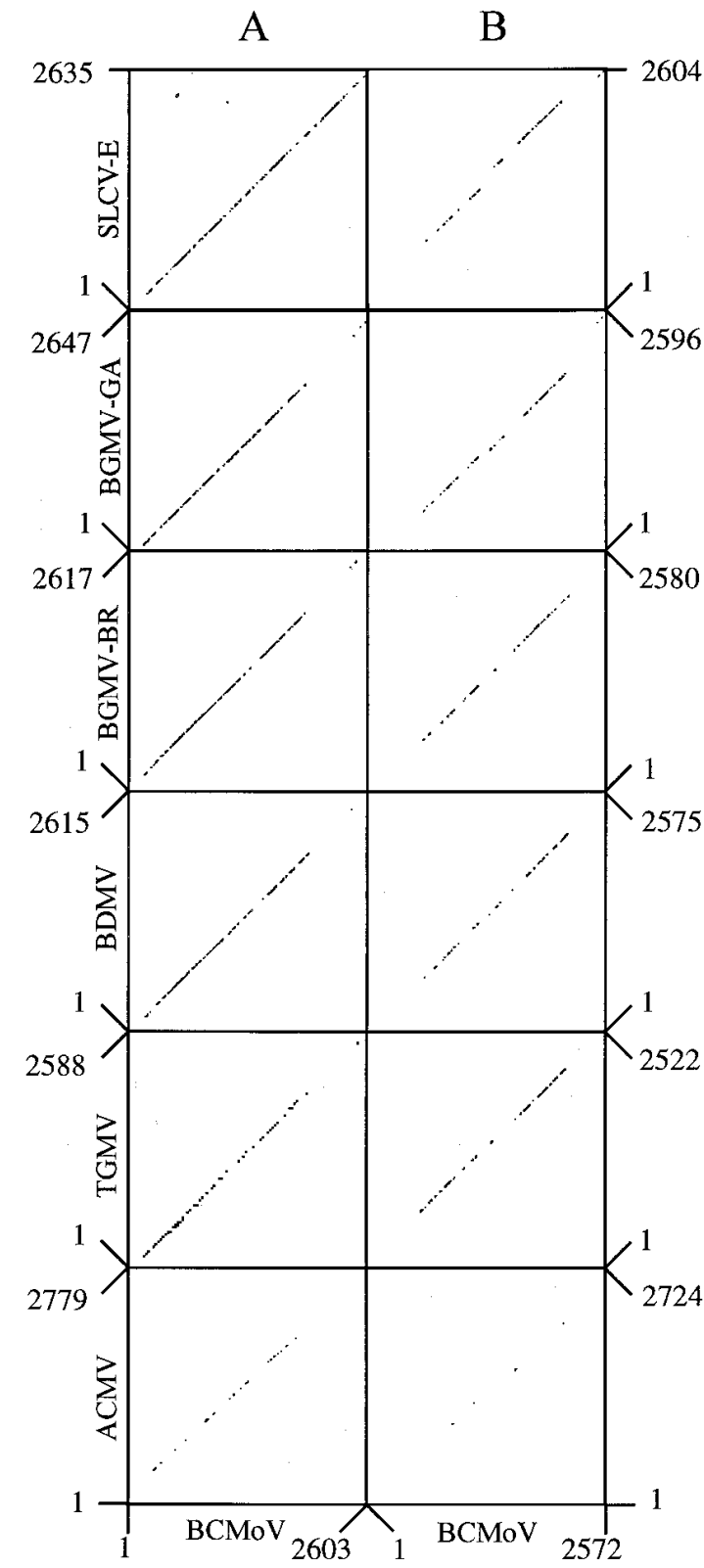

Fig. 3. Distribution of high nucleotide sequence identity among bean calico mosaic virus $(\mathrm{BCMoV})$ and other selected begomoviruses. Presented are dot matrix plots of BCMoV DNA-A or -B nucleotide sequences compared with the corresponding DNA components of an Old World begomovirus that does not infect bean (African cassava mosaic virus [ACMV]), and New World begomoviruses isolated from bean (bean golden mosaic virus [BGMV] Guatemala [GA] and Brazil [BR] and bean dwarf mosaic virus [BDMV]), or from other hosts but which are well adapted (squash leaf curl virus-E [SLCV-E]) or poorly adapted (tomato golden mosaic virus [TGMV]) to bean. Dot matrix plots were generated using the DNA Inspector IIe program with a window size of $20 \mathrm{nt}$ and a mismatch tolerance of three nucleotides per window. Each dot indicates a window in which nucleotide sequence identity was high $(\geq 85 \%)$. Numbers denote nucleotide coordinates; in all cases, nucleotide 1 was defined as the A residue immediately $3^{\prime}$ of the Rep nick site within the common region.
Genome organization of $\mathrm{BCMoV}$ and similarity to other geminiviruses. The complete nucleotide sequences of $\mathrm{BCMoV}$ DNA-A and -B were determined to be 2,603 and 2,572 nucleotides, respectively. The $\mathrm{BCMoV}$ genome organization was typical of a bipartite begomovirus (Fig. 2), encoding all of the ORFs conserved among bipartite begomoviruses. Although the AC2 ORF of $\mathrm{BCMoV}$ potentially could be initiated by an in-frame methionine codon at nucleotide 1,597 , a second in-frame methionine codon at nucleotide 1,468 corresponded to the characteristic begomovirus AC2 start codon that would yield a protein similar in size and peptide sequence to those of most other bipartite begomoviruses.

Comparison of nucleotide sequence identities of the $\mathrm{BCMoV}$ genome components with those of selected geminiviruses is presented in Table 1. BCMoV DNA-A shares 80.1 and $80.7 \%$ nucleotide sequence identity with the A components of its two closest relatives, SLCV-E (36) and CaLCV (1), respectively. BCMoV DNA-B shares 70.7 and $63.4 \%$ nucleotide sequence identity with the B components of SLCV-E and CaLCV, respectively. The CP encoding AV1 ORF was the most highly conserved ORF among BCMoV and SLCV-E at $86 \%$ nucleotide sequence identity. The distribution of high $(>85 \%)$ nucleotide sequence identity among BCMoV DNA-A or DNA-B and the corresponding components of selected begomoviruses is presented as dot matrix plots in Figure 3. Examination of the dot matrix plots indicates that regions of the $\mathrm{BCMoV}$ genome have diverged from other begomoviruses of the New World, although extensive regions of high nucleotide sequence identity are retained within most of the coding regions. Surprisingly, the retention and distribution of high nucleotide sequence identity among BCMoV and other New World begomoviruses isolated from bean (BGMV-GA, BGMV-BR, and BDMV) was not much greater than that for $\mathrm{BCMoV}$ and TGMV, a virus recovered from tomato (25) and poorly adapted to bean when experimentally inoculated (47). As predicted from the overall nucleotide sequence identity values presented in Table 1, the retention and distribution of high nucleotide sequence identity among BCMoV and SLCV-E, the latter which experimentally infects bean (36) but has never been

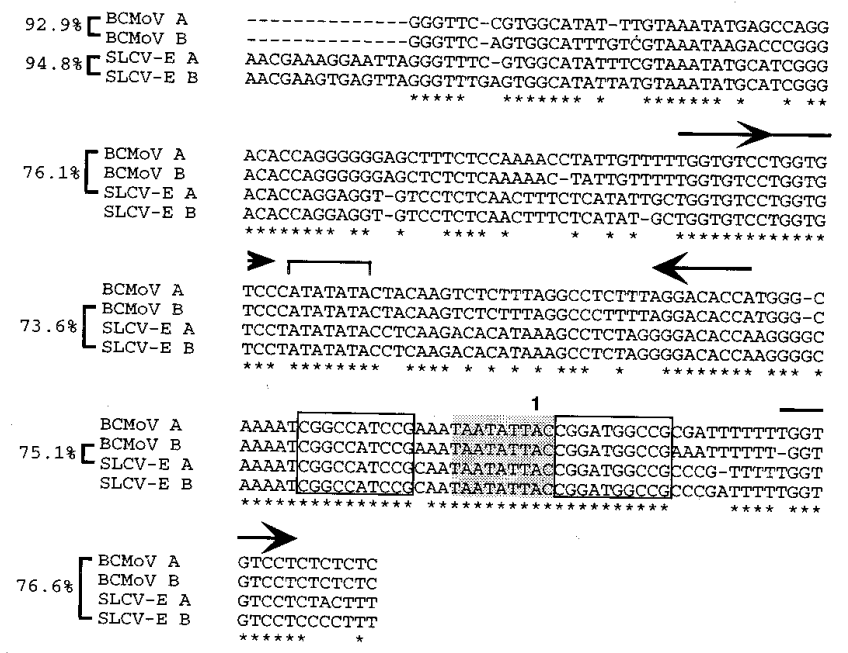

Fig. 4. Alignment of bean calico mosaic virus (BCMoV) common region (CR) sequences with those of squash leaf curl virus-E (SLCV-E). Percent values at left denote the overall identity of common region (CR) sequences in each possible two-way comparison. The first 14 nucleotides of the CR of SLCV-E were excluded in calculating percent identity values with the CR of BCMoV. Asterisks denote the positions of nucleotides conserved among all sequences presented. Shaded box indicates the location of the nine-nucleotide invariant sequence containing the Rep nick site. The A residue immediately $3^{\prime}$ of the Rep protein nick site is designated as nucleotide 1 . Open rectangles denote limits of inverted repeats within the stem-loop motif of the ori. Arrows denote the location and polarity of repeated origin of replication (ori) iterons that are conserved among $\mathrm{BCMoV}$ and SLCV-E. The two iterons that are directly repeated comprise the Rep binding site that serves as a cis-acting element of ori recognition. The location of the AC1 open reading frame (ORF) TATA box is bracketed. 
isolated from naturally infected bean, was greater than that observed for the other viruses compared with $\mathrm{BCMoV}$ in dot matrix plots (Fig. 3). Interestingly, the region of DNA-A encoding the 5'proximal half of the AC1 ORF and the overlapping AC4 ORF was the most divergent coding region among the viruses compared. Within this region, SLCV-E was the only bean-infecting virus to retain windows of high nucleotide sequence identity with BCMoV (Fig. 3), although a similar distribution of high nucleotide sequence identity was observed when BCMoV was compared with CaLCV and TPVTAM (data not shown). In addition, the retention of high nucleotide sequence identity distributed within the CR was also greater among $\mathrm{BCMoV}$ and SLCV-E than among BCMoV and other begomoviruses.

\section{A}

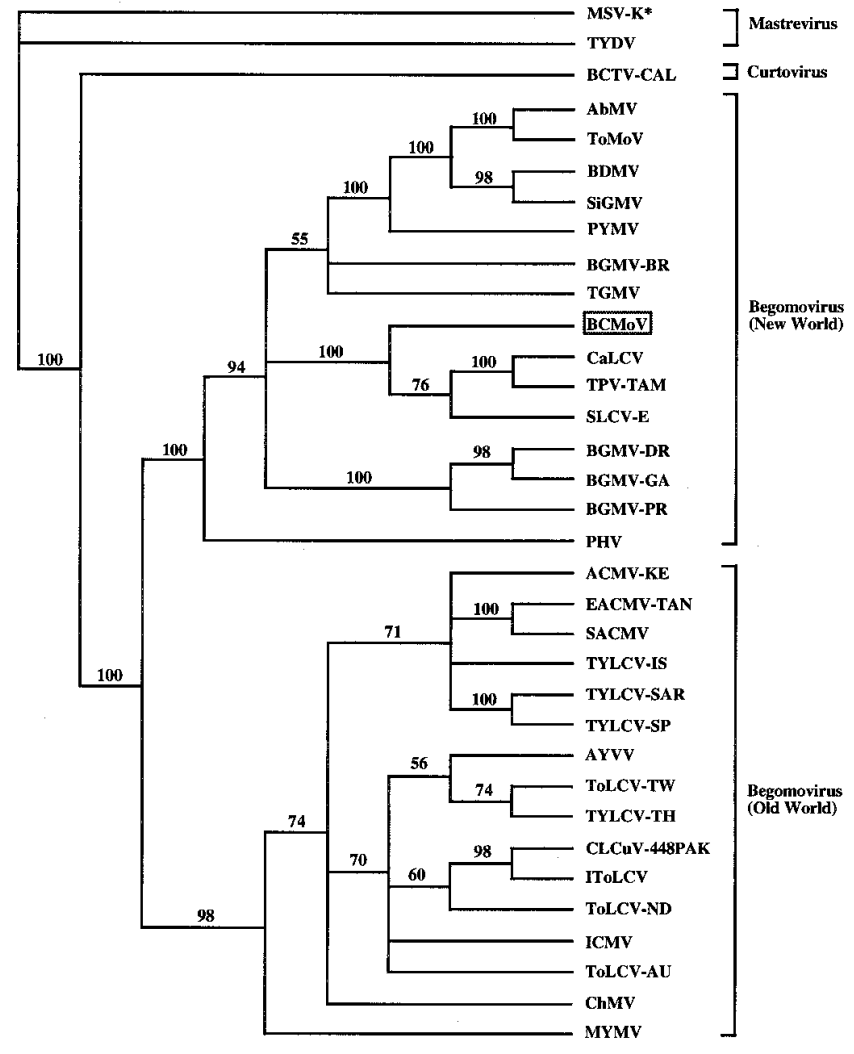

B

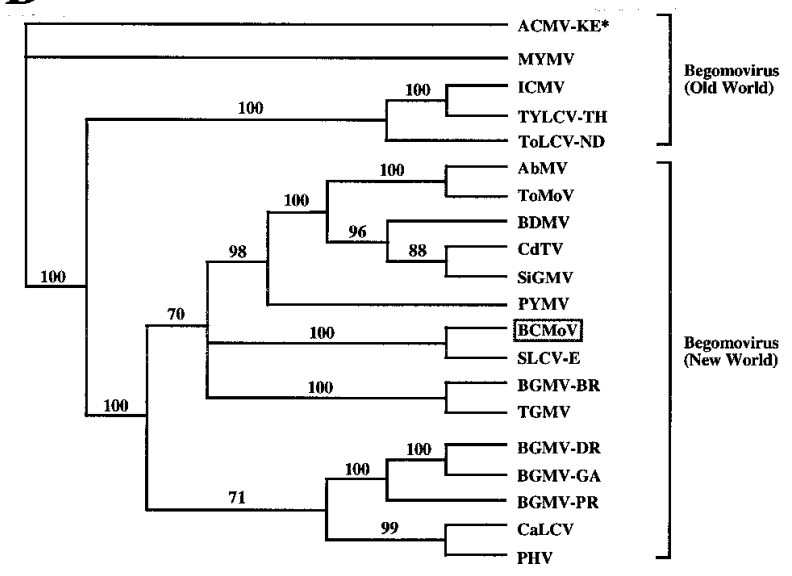

Fig. 5. Phylogenetic reconstruction showing predicted relationships among A, DNA-A or B, DNA-B of select geminiviruses and bean calico mosaic virus $(\mathrm{BCMoV})$. Both vertical and horizontal branch lengths are arbitrary; only tree topology is relevant. Numbers along branches indicate bootstrap percentage values assigned to each node. Asterisks denote taxa used as outgroups. The placement of $\mathrm{BCMoV}$ in each tree is highlighted with a rectangle. Genus affiliations of taxa are indicated at right.
Of the begomoviruses compared in Figure 3, BCMoV shared the least amount of high sequence identity with ACMV-KE (originating from the Old World), particularly when DNA-B sequences were compared.

Alignment of CR sequences of BCMoV and SLCV-E is presented in Figure 4. CR sequences of BCMoV DNA-A and -B were highly conserved $(92.9 \%)$, confirming that the cloned genome components represent a cognate pair. In contrast, comparison of nucleotide sequence identities among the CR of BCMoV and SLCV$\mathrm{E}$ ( 73.6 to $76.6 \%$ identity) indicated that these two viruses have diverged in sequence, particularly in portions of the CR not demonstrated to play crucial roles in ori function or gene expression. Despite these differences in nucleotide sequences among the CRs of BCMoV and SLCV-E, the two viruses retained $100 \%$ sequence identity within modular cis-acting motifs essential for ori function and Rep protein recognition (Fig. 4). Comparison of $\mathrm{CR}$ sequences among $\mathrm{BCMoV}$ and CaLCV or TPV-TAM indicated that the CR of these viruses had diverged more from BCMoV than had SLCV-E, and cis-acting elements of the ori contained several nucleotide substitutions (data not shown).

Phylogenetic relationships of $\mathrm{BCMoV}$ to other geminiviruses. Phylogenetic comparisons of BCMoV DNA-A and DNA-B with reference geminiviruses are shown in Figure 5A and B. DNA-A and monopartite genome comparisons (Fig. 5A) indicated placement of $\mathrm{BCMoV}$ in the clade containing the New World begomoviruses, SLCV-E, CaLCV, and TPV-TAM. By these comparisons, BCMoV is distinct from other begomoviruses isolated from bean in the New World, including three BGMV isolates (DR, GA, and PR) from the Caribbean Basin, BGMV-BR, and BDMV. BCMoV also is clearly distinct from the bean-infecting Old World begomovirus MYMV. Phylogenetic placement of begomovirus taxa based on DNA-B comparisons (Fig. 5B) differed from that based on DNA-A. Although BCMoV DNA-B shares a most recent common ancestor with DNA-B of SLCV-E, the CaLCV DNA-B clustered in a separate clade with PHV DNA-B. Other rearrangements of taxa among the two trees also were observed. The relationship of TPV-TAM DNA-B to other bipartite begomoviruses cannot be assessed because the nucleotide sequence is not available.

\section{DISCUSSION}

This analysis of biotic, molecular, and phylogenetic properties of $\mathrm{BCMoV}$ clearly indicates that $\mathrm{BCMoV}$ is a distinct bipartite species of the genus Begomovirus that may be distinguished from all other bean-infecting geminiviruses presently known from either hemisphere. As cloned DNA inoculum yielded progeny virus with host range, symptom expression, and whitefly transmission properties identical to those of the native virus culture, the cloned $\mathrm{BCMoV}$ components represent the authentic genome of the virus responsible for bean calico mosaic disease of Northwestern Mexico.

Nucleotide sequence identity and phylogenetic analyses indicate that $\mathrm{BCMoV}$ is closely related to SLCV-E. The perfect $(100 \%)$ conservation of nucleotide sequences within cis-acting elements of the ori among BCMoV and SLCV-E is intriguing and raises the possibility that the two viruses may produce viable reassortants. Although trans-replication is often restricted to strains of a single begomovirus, there are exceptions: ToMoV and BDMV (22). The current model of geminivirus ori recognition and function predicts that the Rep proteins of BCMoV and SLCV may be functionally interchangeable and able to trans-replicate heterologous components. However, trans-replication may or may not suffice to produce viable reassortants that are capable of systemic movement or transmission by whiteflies. Because BCMoV and SLCV host ranges partially overlap, and because both viruses occur in the same geographic region, interactions between these viruses are of particular interest.

DNA-A sequence comparisons indicate that $\mathrm{BCMoV}$ is most closely related to the New World bipartite begomoviruses SLCV$\mathrm{E}, \mathrm{CaLCV}$, and TPV-TAM. The A component of these four viruses 
constitutes a clade sufficiently divergent from other begomoviruses to be recognized as a distinct cluster within the genus $\mathrm{Be}$ gomovirus. It is interesting to note that $\mathrm{BCMoV}$ DNA-A clusters with viruses that do not, or have not been demonstrated to, naturally infect bean. Furthermore, several of these viruses (e.g., SLCV and TPV) have geographic distributions (56) that overlap that of $\mathrm{BCMoV}$; whereas other bean-adapted begomoviruses of the New World (e.g., BGMV from the Caribbean, BGMV-BR, and BDMV) do not. This observation suggests that the divergence of A components of the SLCV cluster from a single common ancestor may have been driven by differential host selection pressures. These hypothesized selection pressures may reflect direct effects on DNA-A fitness imposed by different host species, or indirect effects, where isolation of the diverging A components in different hosts was maintained by host range determinants of cognate B components. Migration and subsequent divergence of bean-adapted viruses from other regions of the New World does not account for the present diversity of begomoviruses of the Sonoran Desert, although there are documented examples of humanassisted migration, e.g., beet severe curly top virus, formerly known as BCTV-Iran (3), and TYLCV-IS $(40,49)$. Migration (after or during the process of host adaptation and divergence) would seem to account for the current distribution of CaLCV, known only from Florida (1), a hypothesis strengthened by the recent discovery of a tobacco-infecting begomovirus from Chiapas, Mexico, tobacco apical stunt virus (TbASV) (46), that may constitute the closest CaLCV relative (ORF AV1 identity $>87 \%$, GenBank Accession AFO76855) (1) discovered to date.

Phylogenetic relationships among the DNA-B of begomoviruses sometimes differ from their cognate A components, suggesting different evolutionary histories. In the case of $\mathrm{BCMoV}$ and SLCV-E, the close relationship of the B components indicates that they are derived from a recent common ancestor. As DNA-A of these two viruses are also quite similar, divergence of cognate components of a common ancestor after isolation in different hosts would account for the extant genomes of $\mathrm{BCMoV}$ and SLCV-E. In contrast, CaLCV DNA-A and DNA-B appear to have quite different evolutionary histories. This apparent discrepancy could be explained by the following hypothesis: CaLCV DNA-A diverged from other species of the SLCV cluster as described above. CaLCV DNA-B may reflect a recombination event in which CaLCV DNA-A recombined with a B component ancestor (closely related to $\mathrm{PHV}$ ) bearing $\mathrm{BV} 1$ and $\mathrm{BC} 1$ movement genes well-adapted to hosts in the Brassicaceae. The resulting chimera would then have CR sequences of CaLCV (required for trans-replication) and appropriate movement genes. Such a mechanism would facilitate genetic isolation and subsequent divergence of the interspecies recombinant. Though we cannot directly test this hypothesis in this specific case, we note that several extant and naturally occurring geminiviruses resulted from interspecies recombination $(2,34,58)$. Furthermore, experimental passage of a poorly adapted reassortant (ToMoV DNA-A and BDMV DNA-B) led to replacement of the BDMV DNA-B CR with that of ToMoV DNA-A to produce a novel cognate pair sharing ToMoV CR sequences and displaying enhanced fitness phentoypes (28). Although the proposed hypothesis of component reassortment and recombination is tenable and may explain some aspects of geminivirus evolution, it is likely that other processes have occurred as well, perhaps even concurrently. In particular, it is possible that rapid sequence divergence may occur in the absence of recombination, for example during adaptation to a new host. It is also possible that there are differences in the rate of mutation fixation (molecular "clock") on different branches of the tree, and that these differences contribute to the observed differences in branching order deduced from phylogenetic analysis.

Intensification of agricultural practices, coupled with the upsurge of indigenous A biotype vector populations beginning in 1975 to the late 1980s (5) and the introduction of the polyphagous B biotype vector $(8,13)$ that has displaced the A biotype, has un- doubtedly contributed to the emergence of host-adapted begomoviruses. $\mathrm{BCMoV}$ represents but one example of the numerous begomoviruses that have emerged and cause significant disease in the Sonoran Desert agroecosystem. Several other begomoviruses of the Sonoran Desert await more thorough characterization. In particular, tomato leaf crumple virus (TLCrV), chino del tomate virus (CdTV), and Sinaloa tomato leaf curl virus (STLCV) are tomatoinfecting viruses for which interrelationships remain in question $(10,30,44,56)$. There also exists within the region a complex of partially characterized begomoviruses isolated from pepper that include TPV (53), serrano golden mosaic virus (11), and pepper mild tigre virus (6). Phylogenetic analyses of complete nucleotide sequences of these viruses will be useful for understanding the evolution and diversification of bipartite begomoviruses.

\section{ACKNOWLEDGMENTS}

Mention of proprietary or brand names is necessary to report factually on available data; however, the USDA neither guarantees nor warrants the standard of the product, and the use of the name by USDA implies no approval to the exclusion of others that also may be suitable. The authors would like to acknowledge the contribution of Meg Chapman to experimental host range studies of native BCMoV. We thank Roy French, Les Lane, and Tim Petty for helpful comments. This research was supported in part by a grant from USDA/OICD/FAS to JKB.

\section{LITERATURE CITED}

1. Abouzid, A. M., Hiebert, E., and Strandberg, J. O. 1992. Cloning, identification, and partial sequencing of the genomic components of a geminivirus infecting the Brassicaceae. (Abstr.) Phytopathology 82:1070.

2. Briddon, R. W., Bedford, I. D., Tsai, J. H., and Markham, P. G. 1996. Analysis of the nucleotide sequence of the treehopper-transmitted geminivirus, tomato pseudo curly top virus, suggests a recombinant origin. Virology 219:387-394.

3. Briddon, R. W., Stenger, D. C., Bedford, I. D., Stanley, J., and Markham, P. G. 1998. Comparison of a beet curly top virus isolate originating from the old world with those of the new world. Eur. J. Plant Pathol. 104:77-84.

4. Brown, J. K. 1996. The biology and molecular epidemiology of the Geminiviridae Subgroup III. Pages 125-195 in: Plant-Microbe Interactions Review Series. G. Stacey and N. Keen, eds. Chapman \& Hall, New York.

5. Brown, J. K., and Bird, J. 1992. Whitefly-transmitted geminiviruses and associated disorders in the Americas and the Caribbean Basin. Plant Dis. 76:220-225.

6. Brown, J. K., Campodonico, O. P., and Nelson, M. R. 1989. A whiteflytransmitted geminivirus from peppers with tigre disease. Plant Dis. 73: 610 .

7. Brown, J. K., Chapman, M. A., and Nelson, M. R. 1990. Bean calico mosaic, a new disease of bean caused by a whitefly-transmitted geminivirus. Plant Dis. 74:81.

8. Brown, J. K., Coats, S., Bedford, I. D., Markham, P. G., Bird, J., and Frohlich, D. R. 1995. Characterization and distribution of esterase electromorphs in the whitefly, Bemisia tabaci (Genn.) (Homoptera:Aleyrodidae). Biochem. Genet. 33:205-214.

9. Brown, J. K., Jimenez-Garcia, E., and Nelson, M. R. 1988. Bean calico mosaic virus, a newly described geminivirus of bean. Phytopathology (Abstr.) 78:1579.

10. Brown, J. K., and Nelson, M. R. 1988. Transmission, host range, and virus-vector relationships of chino del tomate virus, a whitefly-transmitted geminivirus from Sinaloa, Mexico. Plant Dis. 72:866-869.

11. Brown, J. K., and Poulos, B. T. 1990. Serrano golden mosaic virus: A newly identified whitefly-transmitted geminivirus of pepper and tomato in the United States and Mexico. Plant Dis. 74:720.

12. Choi, I.-R., and Stenger, D. C. 1995. Strain-specific determinants of beet curly top virus DNA replication. Virology 206:904-912.

13. Costa, H. S., and Brown, J. K. 1991. Variation in biological characteristics and in esterase patterns among populations of Bemisia tabaci (Genn.) and the association of one population with silverleaf symptom development. Entomol. Exp. Appl. 61:211-219.

14. Doyle, J. J., and Doyle, J. L. 1987. A rapid DNA isolation procedure for small quantities of fresh leaf tissue. Phytochem. Bull. 19:11-15.

15. Duffus, J. E., Liu, H.-Y., and Johns, M. R. 1985. Melon leaf curl virusA new gemini virus with host and serological variations from squash leaf curl virus. (Abstr.) Phytopathology 75:1312.

16. Etessami, P., Callis, R., Ellwood, S., and Stanley, J. 1988. Delimitation of essential genes of cassava latent virus DNA 2. Nucleic Acids Res. 
$16: 4811-4829$

17. Faria, J. C., Gilbertson, R. L., Hanson, S. F., Morales, F. J., Ahlquist, P., Loniello, A. O., and Maxwell, D. P. 1994. Bean golden mosaic geminivirus type II isolates from the Dominican Republic and Guatemala: Nucleotide sequences, infectious pseudorecombinants, and phylogenetic relationships. Phytopathology 84:321-329.

18. Fontes, E. P. B., Eagle, P. A., Sipe, P. A., Luckow, V. A., and HanleyBowdoin, L. 1994. Interaction between a geminivirus replication protein and origin DNA is essential for virus replication. J. Biol. Chem. 269: 8459-8465.

19. Fontes, E. P. B., Gladfelter, H. J., Schaffer, R. L., Petty, I. T. D., and Hanley-Bowdoin, L. 1994. Geminivirus replication origins have a modular organization. Plant Cell 6:405-416.

20. Fontes, E. P. B., Luckow, V. A., and Hanley-Bowdoin, L. 1992. A geminivirus replication protein is a sequence-specific DNA binding protein. Plant Cell 4:597-608.

21. Gilbertson, R. L., Faria, J. C., Ahlquist, P., and Maxwell, D. P. 1993. Genetic diversity in geminiviruses causing bean golden mosaic disease: The nucleotide sequence of the infectious cloned DNA components of a Brazilian isolate of bean golden mosaic geminivirus. Phytopathology 83:709-715.

22. Gilbertson, R. L., Hidayat, S. H., Paplomatas, E. J., Rojas, M. R., Hou, Y.-M., and Maxwell, D. P. 1993. Pseudorecombination between infectious cloned DNA components of tomato mottle and bean dwarf mosaic geminiviruses. J. Gen. Virol. 74:23-31.

23. Gladfelter, H. J., Eagle, P. A., Fontes, E. P. B., Batts, L., and HanleyBowdoin, L. 1997. Two domains of the AL1 protein mediate geminivirus origin recognition. Virology 239:186-197.

24. Haley, A., Richardson, K., Zhan, X., and Morris, B. 1995. Mutagenesis of the $\mathrm{BC} 1$ and $\mathrm{BV} 1$ genes of African cassava mosaic virus identifies conserved amino acids that are essential for spread. J. Gen. Virol. 76:1291-1298.

25. Hamilton, W. D. O., Stein, V. E., Coutts, R. H. A., and Buck, K. W. 1984. Complete nucleotide sequence of tomato golden mosaic virus: Potential coding regions and regulatory sequences. EMBO J. 3:2197-2205.

26. Heyraud-Nitschke, F., Schumacher, S., Laufs, J., Schaefer, S., Schell, J., and Gronenborn, B. 1995. Determination of the origin cleavage and joining domain of geminivirus rep proteins. Nucleic Acids Res. 23:910-916.

27. Hidayat, S. H., Gilbertson, R. L., Hanson, S. F., Morales, F. J., Ahlquist, P., Russell, D. R., and Maxwell, D. P. 1993. Complete nucleotide sequences of the infectious cloned DNAs of bean dwarf mosaic geminivirus. Phytopathology 83:181-187.

28. Hou, Y.-M., and Gilbertson, R. L. 1996. Increased pathogenicity in a pseudorecombinant bipartite geminivirus correlates with intermolecular recombination. J. Virol. 70:5430-5436.

29. Howarth, A. J., Caton, J., Bossert, M., and Goodman, R. M. 1985. Nucleotide sequence of bean golden mosaic virus and a model for gene regulation in geminiviruses. Proc. Natl. Acad. Sci. USA 82:3572-3576.

30. Idris, A. M., and Brown, J. K. 1998. Sinaloa tomato leaf curl geminivirus: Biological and molecular evidence for a new subgroup III virus. Phytopathology 88:648-657.

31. Ingham, D. J., Pascal, E., and Lazarowitz, S. G. 1995. Both bipartite movement proteins define viral host range, but only BL1 determines pathogenicity. Virology 207:191-204.

32. Jeffrey, J. L., Pooma, W., and Petty, I. T. D. 1996. Genetic requirements for local and systemic movement of tomato golden mosaic virus in infected plants. Virology 223:208-218.

33. Jupin, I., Hericourt, F., Benz, B., and Gronenborn, B. 1995. DNA replication specificity of TYLCV geminivirus is mediated by the amino-terminal 116 amino acids of the Rep protein. FEBS Lett. 362:116-120.

34. Klute, K. A., Nadler, S. A., and Stenger, D. C. 1996. Horseradish curly top virus is a distinct subgroup II geminivirus species with rep and C4 genes derived from a subgroup III ancestor. J. Gen Virol. 77:1369-1378.

35. Laufs, J., Traut, W., Heyraud, F., Matzeit, V., Rogers, S. G., Schell, J., and Gronenborn, B. 1995. In vitro cleavage and joining at the viral origin of replication by the replication initiator protein of tomato yellow leaf curl virus. Proc. Natl. Acad. Sci. USA 92:3879-3883.

36. Lazarowitz, S. G. 1991. Molecular characterization of two bipartite geminiviruses causing squash leaf curl disease: Role of viral replication and movement functions determining host range. Virology 180:70-80.

37. Lazarowitz, S. G., Wu, L. C., Rogers, S. G., and Elmer, J. S. 1992. Sequence specific interaction with the viral AL1 protein identifies a geminivirus DNA replication origin. Plant Cell 4:799-809.

38. Loniello, A. O., Martinez, R. T., Rojas, M. R., Gilbertson, R. L., Brown, J. K., and Maxwell, D. P. 1992. Molecular characterization of bean calico mosaic geminivirus. (Abstr.) Phytopathology 82:1149.

39. Mayo, M. A., and Pringle, C. R. 1998. Virus Taxonomy-1997. J. Gen. Virol. 79:649-657.

40. Nakhla, M. K., Maxwell, D. P., Martinez, R. T., Carvalho, M. G., and Gilbertson, R. L. 1994. Widespread occurrence of the eastern Mediterranean strain of tomato yellow leaf curl geminivirus in tomatoes in the Dominican Republic. Plant Dis. 78:926.

41. Orozco, B. M., Gladfelter, H. J., Settlage, S. B., Eagle, P. A., Gentry, R. N., and Hanley-Bowdoin, L. 1998. Multiple cis elements contribute to geminivirus origin function. Virology 242:346-356.

42. Orozco, B. M., Miller, A. B., Settlage, S. B., and Hanley-Bowdoin, L. 1997. Functional domains of a geminivirus replication protein. J. Biol. Chem. 272:9840-9846.

43. Padidam, M., Beachy, R. N., Fauquet, C. M. 1995. Classification and identification of geminiviruses using sequence comparisons. J. Gen. Virol. 76:249-263

44. Paplomatas, E. J., Patel, V. P., Hou, Y.-M., Noueiry, A. O., and Gilbertson, R. L. 1994. Molecular characterization of a new sap-transmissible bipartite genome geminivirus infecting tomatoes in Mexico. Phytopathology 84: 1215-1224.

45. Pascal, E., Sanderfoot, A. A., Ward, B. M., Medville, R., Turgeon, R., and Lazarowitz, S. G. 1994. The geminivirus BR1 movement protein binds single-stranded DNA and localizes to the cell nucleus. Plant Cell 6:995-1006.

46. Paximadis, M., Idris, A. M., Torres-Jerez, I., Villareal, A., Rey, M. C., and Brown, J. K. Characterization of geminiviruses of tobacco in the Old and New World. Arch. Virol. In press.

47. Petty, I. T. D., Miller, C. G., Meade-Hash, T. J., and Schaffer, R. L. 1995. Complementable and non-complementable host adaptation defects in bipartite geminiviruses. Virology 212:263-267.

48. Polston, J. E., and Anderson, P. K. 1997. The emergence of whitefly-transmitted geminiviruses in tomato in the Western Hemisphere. Plant Dis. 81: 1358-1369.

49. Polston, J. E., Bois, D., Serra, C.-A., and Concepcion, S. 1994. First report of a tomato yellow leaf curl-like geminivirus in the Western Hemisphere. Plant Dis. 78:831

50. Rosell, R. C., Torres-Jerez, I., and Brown, J. K. Temporal pathway of geminivirus in whitefly extracts, saliva, hemolymph, and honeydew. Phytopathology. In press.

51. Sanderfoot, A. A., and Lazarowitz, S. G. 1995. Cooperation in viral movement: The geminivirus BL1 movement protein interacts with BR1 and redirects it from the nucleus to the cell periphery. Plant Cell 7:1185-1194.

52. Schaffer, R. L., Miller, C. G., and Petty, I. T. D. 1995. Virus and hostspecific adaptations in the $B L 1$ and $B R 1$ genes of bipartite geminiviruses. Virology 214:330-338.

53. Stenger, D. C., Duffus, J. E., and Villalon, B. 1990. Biological and genomic properties of a geminivirus isolated from pepper. Phytopathology 80:704-709.

54. Swanson, M. M., Brown, J. K., Poulos, B. T., and Harrison, B. D. 1992. Genome affinities and epitope profiles of whitefly-transmitted geminiviruses from the Americas. Ann. Appl. Biol. 121:285-296.

55. Swofford, D. L. 1991. PAUP User's Manual. Illinois Natural History Survey, Champaign.

56. Torres-Pacheco, I., Garzon-Tiznado, J. A., Brown, J. K., Becerra-Flora, A., and Rivera-Bustamante, R. F. 1996. Detection and distribution of geminiviruses in Mexico and the southern United States. Phytopathology 86:1186-1192.

57. Wyatt, S. D., and Brown, J. K. 1996. Detection of subgroup III geminivirus isolates in leaf extracts by degenerate primers and polymerase chain reaction. ogy 86:1288-1293.

58. Zhou, X., Liu, Y., Calvert, L., Munoz, C., Otim-Nape, G. W., Robinson, D. J., and Harrison, B. D. 1997. Evidence that DNA-A of a geminivirus associated with severe cassava mosaic disease in Uganda has arisen by interspecific recombination. J. Gen. Virol. 78:2101-2111. 